$m \geq n t$, on the recommendation of Humboldt, of the ten ma rnetical and meteorological observatories, by the Em. $p$ :ror of Russia, was one of the most valuable fruits of this $\mathrm{j}$ urney.

Among Hansteen's contributions to our knowledge of magnetism, may be mentioned the establishment by him of a period of II'I years as the length of the perio licity of the magnetic declination-a cycle which has $r$ :cently assumed such remarkable significance in connecting astronomical with meteorological and other ter$r$ sstrial phenomena.

Soon after his return from Siberia, the Government voted the necessary sum for building an astronomical and ineteorological observatory at Christiania, which was erected under Hansteen's direction. This observatory has done much good work, of which the meteorological department deserves very special commendation. The trigonometrical and topographical survey of Norway, which was begun in 1837 , was conducted under Hansteen's superintendence.

In 1856 , the completion of his fifty years public services was celebrated, and a medal was struck in commemoration of the event. Shortly after this he ceased to lecture publicly, and in $186 \mathrm{I}$ retired from public duty.

\section{THE NOTORNIS OF LORD HOWE'S ISLAND}

$T$ HE last number of the Ibis (July 1873 , pl. x.) contains 1 a representation of a very interesting bird, about which, though discovered and described in the last century, naturalists have for a long time been doubting. This is the species said to be first me itioned by Callam in 1783 (Voy. Bot. Bay), and subsequently figured in the works of John White (Journ. Voy. New South Wales, p. 238, App.) and Governor Phillip (Voy. Bot. Bay, p. 273, pl.), and designated by Latham (Ind. Orn. ii. p. 768) Gallinula alba. No specimens are known to have been brought to Europe for upwards of eighty years, and only two are believed to exist in museums-one in that of Liverpool, which was figured by White, and the other in Vienna, now for the first time portrayed. The species is most likely extinct in Norfolk Island, but a passage in a pamphlet by Mr. Edward Hill, published at Sydney in 1870 , scems to show that it may still exist in that of Lord Howe-though, if so, doubtless on the verge of extermination through the pigs, with which the island is said to be overrun, for the bird is believed to be unable to fly. Should any examples be still living, it would certainly be better that their remains should be placed in our museums, than that they should contribute to the formation of pork; and I write these lines that they may attract the attention of some Australian readers of NATURE, who may be disposed to do a good turn to the University of Cambridye.

This bird, which has been variously assigned to the genera Gallinula (moor-hen), Fulica (coot), and Porphyrio, is now referred to the genis Notornis, containing only onc other species, the "Takahe" of New Zealand $(N$. mantelli)-itself nearly, or quite, extirpáted. It was about the size of a barndoor-fowl, with the bill and legs red. The Vienneses pecimensecms to be entirely white; the example at Liverpool is mottled with purple, but not enough to gainsay the name of "White Bird" by which it scems to have been known both in Norfolk and Lord Howe's Islands. It would no doubt, if taken alive, be easily kept in confinement, and I need scarcely say how highly a living example would be valued by the Zoological Society; but this is perhaps more than can be reasonably hoped for, and, so far as I am concerned, I should be well content with a specimen in spirit, or a skin with all the bones accompanying it, for the Cambridge Museum.

I may perhaps be allowed to conclude by remarking that the history, and especially the distribution of the family of birds, to which the subject of this notice refers, is indeed worthy of far more attention than they have hitherto received, and could that accomplished zoological writer who has lately in the columns of a sporting contemporary made the not very distant family of Gruidce the theme of an admirable series of essays-far probably from being fully appreciated by his readers-be induced to employ his pen on the Rallida, the results would be of the greatest interest. The Rails-employing the word in a very wide sense-are cosmopolitan in the highest degree. Some of the best known genera have their representatives all over the world, occurring even in oceanic islands, where birds generally are so scarce-Gallinula and Fulica, for instance; and some at least of the former, when they get to such remote spots, seem to lose their volatile powers, though otherwise undergoing but little change, as witness the $G$. nesiotis of Tristan d'Acunha, made known a few years ago by Mr. Sclater, and a form still undescribed, of which three examples were obtained by $\mathrm{my}$ brother from Denis Island, an outlier of the Seychelles group (Ibis, 1867, p. 358 ). Then there is a genus equally fightless, which has lately been restored to light and knowledge, but, alas ! too late for us to know it in the flesh. This is the Aphanapteryx, which survives only in a few bones, recovered from the mud of a Mauritian lake, and now in the Cambridge Museum, a painting at Vienna, and a few notices by early voyagers-a bird with a long bill and dishevelled plumage, almost, it would seem, like that of the Apteryx. In the opposite direction almost, as to structure, we have Iribonyx; but I should occupy far too much space were I now to dwell upon even the chief forms of the family. From whatever point of view it be regarded, it will be found one of the most interesting in the whole series of birds.

\section{Alfred NeIWTON}

\section{ASTRONOMICAL ALMANACS*}

II.

II.-The "Connaissance des Temps," under the direction of the Academy of Sciences

THE first to whom the Academy entrusted the editorship of these Ephemerides was Lieutaud.

The only real modification introduced into the volume was the substitution, for the table of refractions published by Lefebvre, of a table of the refractions of Cassini, giving the values of that quantity in minutes and seconds for all degrees of height, from $0^{\circ}$ to $90^{\circ}$. The book was also somewhat increased in size. In 1707 Lieutaud introduced into the Connaissance des Temps a notice of the occultations of stars, the observation of which is of use in determining longitudes. Lieutaud edited the Connaissance des Temps till 1730 , when it passed into the hands of a young academician, Louis Godin.

Godin, a pupil of Delisle, was born at Paris on February 28, 1704, and entered the Academy as éleve at the agc of 21 years. He was then known only by a keen desire for knowledge and a strong predilection for astronomy. On taking the direction of the Connaissance des Temps, he suppressed the aspects of the planets, which were useless, and introduced the right ascension of the sun for every day of the year: calculated this co-ordinate and the declination to a second, and added the eclipses of the satellites of Jupiter, so that the Connaissance des Temps contained from this time the announcement of the eclipses of the supcrior satellites.

In 1735 Godin set out for Peru for the purpose of measuring with Bouguer and La Condamine an arc of one degree of the meridian, and to Jean-Dominique Maraldi, grand-nephew of Cassini the elder, was committed the care of the Connaissance des Temps. He enriched the work with the configuration of the satellites of Jupiter for every day in the year, but he suppressed the notice of occultations,

\footnotetext{
* Continued from p. 3rz.
} 
agreat mistake, certainly; though perhaps these phenomena were of little service in his time. Having become a pensionnaire of the Academy in I 760 , he resigned the editorship of the Connaissance des Temps to Joseph-Jerôme Le François de Lalande.

De Lalande, born at Bourg-en-Bresse, July II, I732, was sent at the age of 20 to Berlin, under the patronage of Le Monnicr, his master, to take observations of the moon, which, combined with those which La Caille at that time effected at the Cape of Good Hope, were the means of giving the parallax of that planet. On his return he was presented to a place vacant for many years in the Academy, and shortly after, in $I 760$, he was entrusted with the editorship of the Connaissance des Temps. A distinguished astronomer, possessing a thorough knowledge of all the advances which had been made during later years in astronomical science, Lalande very much improved the work of which he had charge. We shall mention the most important of the changes which are due to him.

His first care was to take for the basis of his calculations new tables, more exact than those which Godin had continued to employ. He employed for the sun the tables of the Abbé of La Caille; for the moon, those of Tobie Mayer $*$ for the planets, the tables of Cassini ; and for the eclipses of the satellites of Jupiter, those of the Swede Wargentin, of which he had published a new edition. The rising of the sun and the planets is calculated for the true noon of each day ; but, says Lalande, "the Connaissance des Temps being intended mainly for astronomers, the positions of the moon are given for the instant of her passage across the meridian." The following year, however, "on account of the inconveniences attending such a mode of indication," this astronomer resolved to give the Iongitudes for midday and midnight of each day. Finally, in a short and well-written memoir appended to the Connaissance des Temps, $t$ he investigated the different methods for finding the longitude at sea by a single observation of the moon. Some ycars later he restored the announcement of the occultation of stars.

In 1774 , the Connaissance received from Jerôme Lalande a most important improvement, which was the means of making this work, hitherto almost exclusively intended for astronomers, of great use to mariners. But, before stating in what this modification consisted, some historical details are necessary concerning one who was the real pioncer, and at the same time one of the glories of French astronomy in the 18 th century.

In 1737 , the savant Fouchy presented to Cassini of Thury, son and successor of the first director of the Observatory of Paris, celebrated for his fine work on "The Size and the Figurc of the Earth," a young deacon of 23 years, who, alone, without instruments and almost without books, had acquired a remarkable astronomical cducation. Cassini welcomed the protégé of Fouchy, lodged him at the Observatory, and allowed him to take part in his work. This young Abbe was Nicolas-Louis de la Caille, born on March I 5, 1713, at Rumigny, near Rozoy, in Thiérache. J. D. Maraldi, grand-nephew of Cassini the first, and who also lived at the Observatory, became his friend, and a year after his arrival $\left(173^{8}\right), \mathrm{La}$ Caille made along with him the geographical description of the coast of France, from Nantes to Bayonne; in 1739 La Caille took part in the work connected with the meridian of France. I Shortly after, Dr. Robbes nominated him professor of mathematics at the Mazarin College. He instituted a small observatory where he made a very large number of observations of rare precision. In 1741 , at

* "Tabularum motuum solis et lunzo et longitudinum methodus pro mots.

t Lalande afterwards rezularly followed the custom of accompanying the Connerssance des Tents with short astronomical memoirs, entitled "Additions to the Connaissance des Temps." This custom has continued to the present day.

present day. lished by $\mathrm{L}_{3}$ Caille in 2;44, and bore the name of Cassini de Thury. the age of 27 years, La Caille entered the Academy of Sciences.

In 1744 the astronomer of the Mazarin College published the first volume of a series of Ephemerides, entitled "Ephémérides des monuments célestes depuis I745 jusq'en 1754," in which he was the first to give-and Lalande afterwards imitated him in the Connaissance des Temps of I760-the distance of the sun at the equinox, or, what amounts to the same thing, the right ascension of the sun in time.

Some years later, in 1749 , La Caille proposed to the Academy that he should spend a year at the Cape of Good Hope, for the purpose of making an accurate catalogue of the stars of the southern sky, intended to replace the first rough sketch made in 1677 , by Halley, at St. Helena; to measure the parallax of the moon, of Venus, and of Mars, by means of comparative observations made simultaneously in Europe; and finally to determine carefully the geographical position of the Cape of Good Hope.*

The proposal of La Caille was adopted, and the StatesGeneral of Holland having given their assent, La Caille set out in $175 \mathrm{I}$, after having published the list of stars which he wished to be observed by the European astro. nomers, for the purpose of rendering his voyage fruitful in scientific results. We do not intend to recount all the incidents of this expedition. Let us, however, mention a fact which illustrates well the character of this astronomer, "reserved, modest, and disinterested." He received for his expedition, the purchase of instruments, and other expenses, for his maintenance and that of an artist, the sum of I0,000 livres; on his return, he found he had spent only 9;145 livres. He scrupulously carried back the balance to the royal treasury; the officials, surprised, would not accept it. "You require it," they said to him; "it will take it to remunerate you." MIoreover, when he set out from the Cane, the minister had charged him to make maps of the Isles of France and of Bourbon, which were not comprised in the original plan, and "for which most others would have asked, and certainly obtained, a supplementary indemnity."

The observations made during this expedition (I75 I and 1752) by La Caille with his telescope of 26 inches focus, and an inch and a half aperture, were published by himself, and after his death, by Maraldi, in $176_{3}$, under the title, "Cœlum australe stelliferum, seu observationes ad construendum stellarum Australius catalogum instituta, in Africa ad Caput Bonæ-spei, à Nicolao-Ludovice Ue La Caille."

A new edition of this catalogue was published in 1847 , under the superintendence and at the expense of the British Association and the British Government, under the editorship of Messrs. Bailly and Henderson, the latter, at the time, Director of the Edinburgh Observatory. $I$

But, besides, this voyage to the Cape of Good Hope had a most important result. During the two journeys, La Caille tested and compared all the methods employed till then to determine longitude at sea. Among these he noted that which the celebrated Halley had given in 1678 , and which is based upon the observation of the distance of the moon from the sun or from a star. The experiments which he made in reference to it having convinced him of its excellence, he strongly recommended it on his return to France; and in his sccond volume of Ephemerides, which commenced in 1755 , he proposed a Nautical Almanac, in which should be found, for every hour of the

- La Caille also purposed to observe the length of the seconds pendulum, the variation of the magnetic needle, asd finally the length of a degree of the meridian at the Cape This has since been measured under the equator, under the Polar Circle, and in various places in Europe; but we do not yet know the value of any degree in the southern hemisphere.

t In the accounts which he rendered on his retury, La Caille has put d)wn only fize sous for his daily expenses, and as ruch for those of a mechanician who accompanied him.

I The Association gave $200 l$. and the Government $x, 000 l$. It is entitled "A Catalogue of 9,766 Stars in the Southern Hemisphere for the berinning of the year 1750 , from the Observation of the Abbe de Ia Caille." 
day, the distance of the moon from the sun and the stars. La Caille regretted that his other occupations would not permit him to compile this nautical Ephemerides himself. At a later time, in his treatise on navigation, he reverted to the same subject, and gave anew the sketch of his almanac, limiting himself to giving the distances every four hours for the meridian. His design was not followed. Lalande contented himself with analysing and discussing La Caille's method in the Connaissance des Temps for I760. As to the French Marine, it was content to use "L'état du Ciel, calculé par Pingré et rapporté à l'usage des marins, 1754, 1755, 1756, et 1758." It was very different, however, in England.

\section{(To be continued.)}

\section{SOUTH AFRICAN MIUSEUII}

THE Cape Argus for July ro contains the report of the 1 curator, Mr. Roland Trimen, of the South African Museum, for the previous half year. Many valuable additions have been made to the museum during that time, but its efficiency is very seriously crippled through want of funds, mainly due, we are sorry to say, to the parsimony of Government. We regret to see that the number of subscribers has seriously diminished from what it originally was, but the success of so valuable an institution should in no way be dependent on the capricious revenue to be derived from such a source. Let us hope that recent changes in the personnel of the Government will lead to greater liberality for this and for other scientific purposes. IVe cannot do better than give a few extracts from an excellent leader in the Argits on the Curator's report.

"Now that strong efforts are being made to forward the interests of education in the Colony, those institutions that aid in the work should not be neglected. We do not at present refer to colleges and schools, for these, whenever education is discussed, come prominently before the popular mind, but our remarks are directed rather to such places as museums, whose work in higher education of the kind required in modern days is of considerable importance . . . It has often struck us as rather a reflection on Cape Town that there is no Society here for the discussion of natural science subjects, and though we are aware of some obstacles to the successful working of such a body, we see no reason why they should not be overcome. In the capital of every Colony of which we have any knowledge, a Society of the kind exists, and indeed in the Cape itself there are towns that, in this respect at least, are ahead of the metropolis.

"But though we have no Natural Science Society in Cape Toivn, we have what, all things considered, may be said to be an excellent Museum. ... The Museum was founded under the enlightened influence of the then Governor, Sir George Grey, in 1855, and in 1857 was incorporated by Act of Parliament. Its first trustees were Mr. Rawson, the Colonial Secretary at the time, Sir Thomas Maclear, the then Astronomer Royal, and Dr. Pappe, the then Colonial Botanist. On Dr: Pappe's death Mr. C. A. Fairbridge was appointed a trustee, and upon the resignation of Mr. Rawson, on his departure from the Colony, his place was filled by Mr. Southey, now Lieut.-Governor of Griqualand West. It will be thus seen that the Museum has from the first been under the management of trustees alike of scientific acquirements and business ability. In its first curator, MIr. Layard, it was extremely fortunate, and it had the advantage of his enthusiastic labours for the lengthy period of fifteen years.

"But though it has had the advantage of excellent management, the development of the institution has been seriously hindered trom want of funds, and it has not received, either from the Legislature or the public, that pecuniary support neces- sary to secure the services of efficient officers and to meet the thousand and one expenses of cases, glass, chemicals, and the appliances and apparatus required in carrying out the work of a museum. It is a wise policy on the part of the Legislature to vote grants of money to such institutions in proportion to the pecuniary support received from the public, and if Parliament is to be induced to make a larger grant to the Museum, the private subscription list must be extended. The small sum of one guinea represents the subscription for a year, and we are quite sure, when it is known how much the institution stands in want of funds, the list of subscribers will be. come larger.

"Strangers who visit the Museum and who know how such things are managed elsewhere must smile when told that its curator is a clerk in the Civil Service, whose time is chiefly occupied in doing the work of a subordinate officer in the Colonial Office. We say this without any intention of disparaging the gentleman referred to, for his attainments in one branch of Science at least are universally admitted ; but we do say that, if the South African Museum is to be anything like worthy of the name, and if it is to continue efficiently to perform the work so well commenced by Mr. Layard, its curator should devote the whole of his time and attention to the duties of that office. Under existing circumstances, that, however, is not to be expected, as the salary is not sufficient to induce any qualified gentleman to give up other positions for the sake of applying himself entirely to the work of the Museum.

"There are other matters connected with this institution to which we might draw attention, but until more public support is given to the Museum it would be a waste of time to refer to them."

\section{GEOLOGICAL MIAP OF AUSTRALIA AND TASIIANIA}

$G$ EOLOGICAL surveys have been proceeding, to a greater or lesser extent, in all the Australian colonies for several years, and in Victoria the work has been prosecuted so systematically, and with such success, that the main features of the surface geology of the country are comparatively well ascertained and mapped out. The example in this respect set by Victoria has been followed to a very considerable extent by Queens. land, and in a lesser degree by several of the other colonies. A geological map of Australia has, however,
never been issued. Such a work would be invaluable, and the materials obtained are quite sufficient to justify an attempt being made to carry it out. Such an attempt is now being made by the Mining Department of Victoria. Some months since the Hon. A. Mackay, Minister of Mines, put himself in communication with the Governments of the other colonies with the view of obtaining from them all the information in their posses. sion respecting the geological characteristics of the territories over which they presided. The application was readily acceded to, and a large mass of materials has been since placed at the disposal of the Mining Department of Victoria. Under the direction of Mr. R. Brough Smyth, F.G.S., Secretary for Mines, this has been thoroughly digested and arranged, and is now being embodied in a map, which, when completed, as it will be shortly, will show at a glance the result of all geological surveys made in Australia and Tasmania up to the pre-
sent time. As the value of such a work necessarily depends upon the accuracy of the observations upon which it is based, it may be well, before attempting a brief description of its main features, to indicate the source from whence the materials used in its compilation have heen derived. The geological skctch

* From an article in the Melesimnse Arsous, July 7. 